\title{
ANTITESTICULAR AND ANTIFERTILITY ACTIVITY OF A PIPECOLINOMETHYLHYDROXYINDANE IN RATS
}

\author{
A. BORIS, G. NG AND J. F. HURLEY \\ Research Division, Hoffmann-La Roche, Inc., \\ Nutley, New Fersey 07110, U.S.A.
}

(Received 13th August 1973)

\begin{abstract}
Summary. Treatment with DL-6-(N- $\alpha$-pipecolinomethyl)-5-hydroxyindane maleate (PMHI) has been found to depress testicular weight and interfere with spermatogenesis and fertility in the male rat. At equal doses by weight, PMHI caused a greater reduction in testicular weight than WIN 18446, nitrofurazone, methallibure and diethylstilboestrol, but lesser reductions in seminal vesicle and ventral prostate weights than were obtained with the two antigonadotrophic compounds, methallibure and diethylstilboestrol. Doses of the compound which were effective in the male rat did not interfere with normal oestrous cycles or fertility when administered to female rats.
\end{abstract}

\section{INTRODUGTION}

Various compounds have been reported which interfere with spermatogenesis and cause infertility in rats and other species. Such agents are of interest because of possible application in human and animal contraception and potential use in pest control. Compounds which affect spermatogenesis are also of interest as tools which may be useful in studies of the spermatogenic process itself. Antispermatogenic compounds have been found in several different chemical classes, and have been the subject of several excellent reviews, notably by Jackson (1970, 1973) and Gomes (1970).

This report presents some data on a new antispermatogenic and antifertility compound, DL-6-(N- $\alpha$-pipecolinomethyl)-5-hydroxy-indane maleate (PMHI). The structure of this compound is shown in Text-fig. 1.

\section{MATERIALS AND METHODS}

All rats in these studies were of the $C D$ strain obtained from the Charles River Breeding Laboratories, Wilmington, Mass. All animals were freely supplied with food and water and were housed in temperature-controlled, air-conditioned quarters. Light and dark periods were alternated at 12-hr intervals. Compounds were administered by gavage in an aqueous suspending vehicle (ASV) which consisted of $0.9 \% \mathrm{NaCl}, 0.9 \%$ benzyl alcohol, $0.5 \%$ carboxymethylcellulose, and $0.4 \%$ polysorbate 80 in distilled water. Concen- 
trations of the administered compounds were adjusted to enable the dosage required to be given in a volume of $0.2 \mathrm{ml} / \mathrm{rat} / \mathrm{day}$. Control animals received the vehicle alone on each of the treatment days. In all experiments, males and females were treated once daily for 21 consecutive days. Vaginal smears were examined daily in the latter to determine possible effects on the oestrous cycle of DL-6-(N- $\alpha$-pipecolinomethyl)-5-hydroxy-indane maleate (PMHI). In those studies in which fertility was assessed, half of the animals in each treatment group were killed on the day after the last treatment day to determine organ weight effects and to obtain testes for histological examination. Testes were processed by standard histological techniques and stained with haematoxylin and eosin.

The remaining rats in each group were used for fertility studies. In breeding experiments, the ratio of males to females was 1 to 2. Pregnant females were permitted to litter at term. In the experiment in which untreated females were mated with treated males, the probable conception date was determined by assuming a 22-day interval between conception and birth. In our experience, the 22-day interval occurs with regularity in this strain of rat.

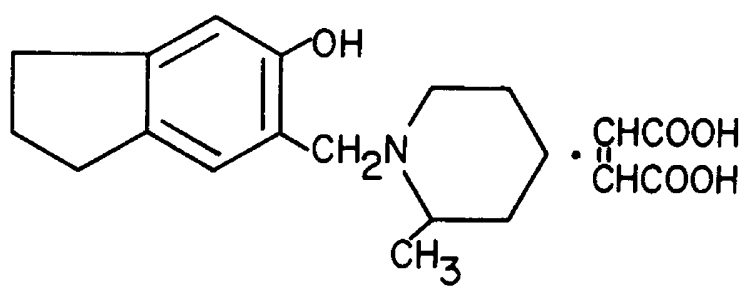

TEXT-FIG. 1. Structure of DL-6-(N- $\alpha$-pipecolinomethyl)-5-hydroxy-indane maleate (PMHI).

\section{RESULTS}

The data shown in Table 1 indicate that PMHI caused significant depression of testicular weight at dosages of $1.5 \mathrm{mg} / \mathrm{kg} /$ day and above when administered orally for 21 days to adult rats. With the exception of the group receiving $6.25 \mathrm{mg} / \mathrm{kg}$, the reduction in ventral prostate weights correlated with decreased testicular weights. Seminal vesicle weight did not follow a similar dose-related pattern. Statistically significant reductions in seminal vesicle weights occurred at the 3 and $50 \mathrm{mg} / \mathrm{kg}$ dosage levels. The effect at $3 \mathrm{mg} / \mathrm{kg}$ was apparently not related to treatment with the compound, since successively higher dosages failed to manifest an effect on the weights of the seminal vesicles. A drugrelated effect at $50 \mathrm{mg} / \mathrm{kg}$ cannot be ruled out, since higher dose levels were not tested. It should be pointed out, however, that when the reduction in body weight gain for the $50 \mathrm{mg} / \mathrm{kg}$ group was considered and seminal vesicle weight was computed in terms of $\mathrm{mg} / 100 \mathrm{~g}$ body weight, there was no significant difference from controls. The apparent increase in absolute thymus weight in the $25 \mathrm{mg} / \mathrm{kg}$ dosage group also was not significant when organ weight relative to body weight was considered. No effects of PMHI were observed on adrenal, thyroid, or pituitary weights. Body weight gain was normal in all dosage groups, 


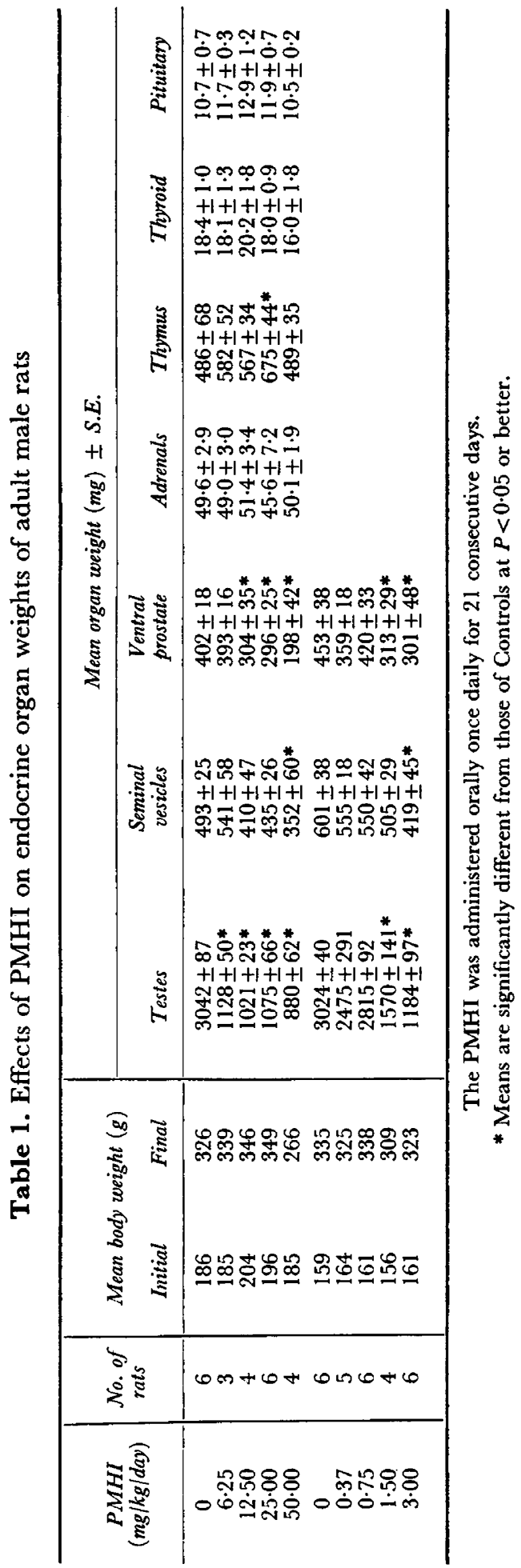


except at the $50 \mathrm{mg} / \mathrm{kg}$ level where a significant decrease in body weight gain was observed.

The effect of PMHI on the fertility of male rats is shown in Table 2. The data indicate that the oral administration of PMHI for 21 days at dosages of $6.25 \mathrm{mg} / \mathrm{kg} /$ day and above caused sterility in all males, which continued to the termination of the experiment 19 weeks after the last treatment with the

Table 2. Fertility of male rats treated orally with PMHI for 21 days

\begin{tabular}{|c|c|c|c|}
\hline \multirow{2}{*}{$\underset{(m g / k g / d a y)}{P M H I}$} & \multicolumn{2}{|c|}{ No. of rats } & \multirow{2}{*}{ 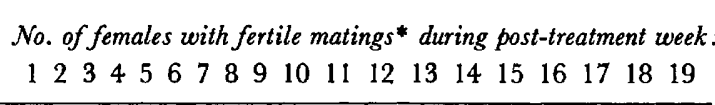 } \\
\hline & Males & Females & \\
\hline $\begin{array}{r}0.37 \\
0.75 \\
1.50 \\
3.00 \\
6.25 \\
12.50 \\
25.00 \\
50.00\end{array}$ & $\begin{array}{l}6 \\
6 \\
5 \\
6 \\
3 \\
4 \\
6 \\
5\end{array}$ & $\begin{array}{r}12 \\
12 \\
10 \\
12 \\
6 \\
8 \\
12 \\
10\end{array}$ & 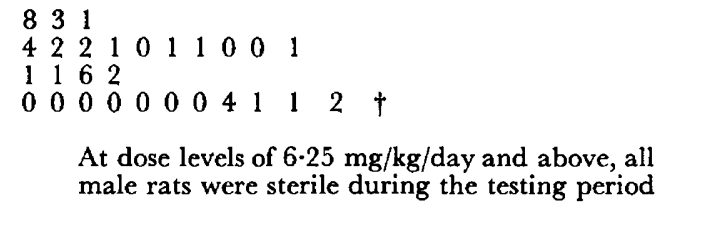 \\
\hline
\end{tabular}

* Rats were tested for fertility for 12 weeks after last treatment day at dosages of 0.37 to 3.0 $\mathrm{mg} / \mathrm{kg} /$ day and for 19 weeks after last treatment day at dosages of 6.25 to $50 \mathrm{mg} / \mathrm{kg} / \mathrm{day}$.

$\dagger$ Four females were not pregnant 12 weeks after treatment of the males.

Table 3. Comparison of the effects of WIN 18446, nitrofurazone, methallibure, diethylstilboestrol and PMHI on sex organ weights in adult male rats

\begin{tabular}{|c|c|c|c|c|c|c|}
\hline \multirow[b]{2}{*}{ Treatment } & \multirow[b]{2}{*}{ No. of rats } & \multirow{2}{*}{\multicolumn{2}{|c|}{$\begin{array}{c}\text { Mean body weight } \\
(g)\end{array}$}} & \multicolumn{3}{|c|}{ Mean organ weight $(m g) \pm S . E}$. \\
\hline & & & & Testes & $\begin{array}{c}\text { Seminal } \\
\text { vesicles }\end{array}$ & $\begin{array}{l}\text { Ventral } \\
\text { prostate }\end{array}$ \\
\hline $\begin{array}{l}\text { Vehicle controls } \\
0.2 \mathrm{ml} / \text { day }\end{array}$ & 8 & 158 & 308 & $3004 \pm 89$ & $435 \pm 43$ & $358 \pm 38$ \\
\hline $\begin{array}{l}\text { WIN } 18446 \\
50 \mathrm{mg} / \mathrm{kg} / \text { day }\end{array}$ & 7 & 165 & 280 & $2214 \pm 170^{*}$ & $455 \pm 36$ & $293 \pm 17$ \\
\hline $\begin{array}{l}\text { Nitrofurazone } \\
50 \mathrm{mg} / \mathrm{kg} / \text { day }\end{array}$ & 7 & 160 & 290 & $1414 \pm 179 *$ & $409 \pm 21$ & $350 \pm 29$ \\
\hline $\begin{array}{l}\text { Methallibure } \\
50 \mathrm{mg} / \mathrm{kg} / \text { day }\end{array}$ & 4 & 157 & 224 & $2072 \pm 189^{*}$ & $49 \pm 13^{*}$ & $46 \pm 13^{*}$ \\
\hline $\begin{array}{c}\text { Diethylstilboestrol } \\
50 \mathrm{mg} / \mathrm{kg} / \text { day }\end{array}$ & 7 & 160 & 162 & $1128 \pm 208^{*}$ & $51 \pm 4^{*}$ & $37 \pm 6^{*}$ \\
\hline $\begin{array}{l}\text { PMHI } \\
50 \mathrm{mg} / \mathrm{kg} / \text { day }\end{array}$ & 8 & 163 & 282 & $868 \pm 54^{*}$ & $255 \pm 19 *$ & $178 \pm 17^{*}$ \\
\hline
\end{tabular}

The compounds were administered orally once daily for 21 consecutive days. WIN 18446: N,Nbis(dichloroacetyl)-1,8-octanediamine. Nitrofurazone: 5-nitro-2-furaldehyde semicarbazone. Methallibure: I-methyl-6-(1-methylallyl)-2,5-dithiobiurea.

* Means are significantly different from those of Controls at $P<0.05$ or better.

compound. All six rats treated with $3 \mathrm{mg} / \mathrm{kg} /$ day of PMHI were sterile during the first 7 weeks of cohabitation and two were still infertile at 12 weeks after treatment. Males receiving 0.37 to $1.5 \mathrm{mg} P M H I / \mathrm{kg} /$ day remained fertile. Treatment with PMHI did not interfere with normal mating and mounting 
PI.ATE 1

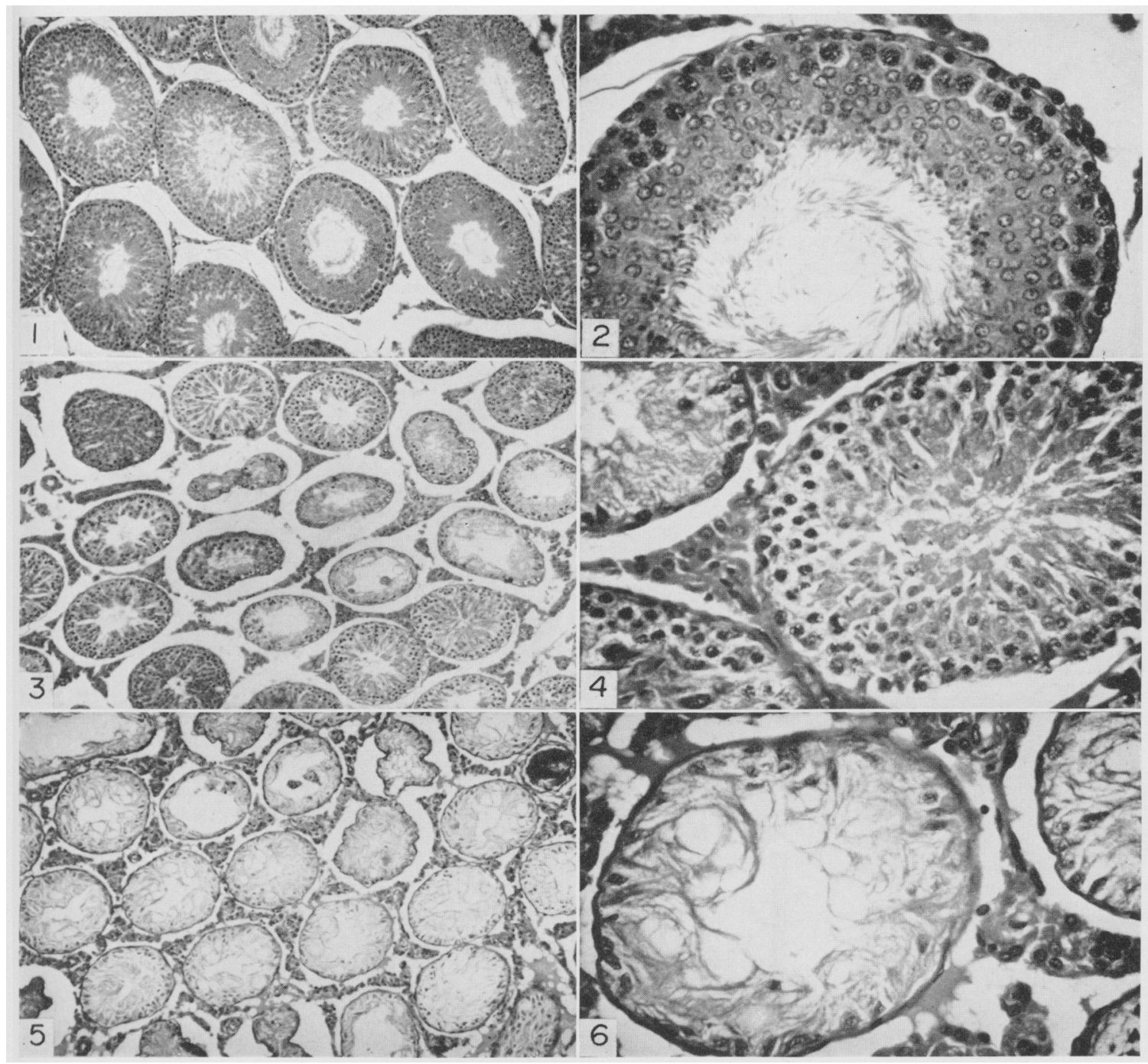

Histological sections of testes from rats treated orally for 21 days. Figs 1.3 and $5 \times 125$; Figs 2, 4 and $6 \times 500$.

Iiss 1 and 2. Normal testis with active spermatogenesis of control rat treated only with the acueous suspending vehicle.

Fics 3 and 4. Mixture of apparently normal and degenerative tubules in the testis of rat treated with $3 \mathrm{mg} P \mathrm{PHH} / \mathrm{kg} / \mathrm{day}$.

lics 5 and 6 . Testis of rat treated with $6.25 \mathrm{mg}$ PMIHI/kg/day. 1 ll tubules show degenerative changes and atrophy. Note the absence of spermatogenic cells, including spermatogonia and the presence of Sertoli cells only. 


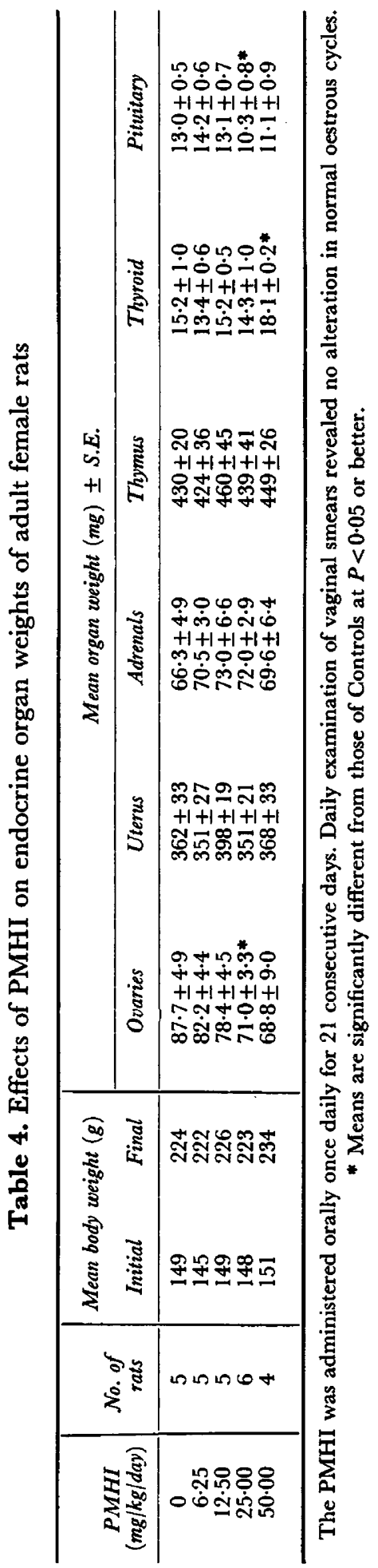


behaviour at any dose level. Representative histological sections of testes from rats killed on the day after the last treatment day are shown in Plate 1. An absence of spermatogenic cells in the section from a rat receiving a daily dose of $6.25 \mathrm{mg} \mathrm{PMHI} / \mathrm{kg}$ is clearly evident.

A comparison of the effects on sex organ weights of PMHI, two known antispermatogenic compounds acting directly on the testes, WIN 18446 (Beyler, Potts, Coulston \& Surrey, 1961) and nitrofurazone (Nelson \& Steinberger, 1953), and two antigonadotrophic compounds, methallibure (Walpole, 1965) and diethylstilboestrol which operate by way of hypothalamic-pituitary suppression, is shown in Table 3. The data indicate that all of the compounds caused a significant reduction of testicular weight, while only the antigonadotrophic compounds and PMHI showed depression of the weights of the accessory sex organs. The most potent compound with respect to testicular weight was PMHI, but it was the least potent compound with regard to depression of the accessory sex organ weights.

As shown in Table 4, PMHI did not cause notable effects upon endocrine organ weights of female rats treated for 21 days with 6.25 to $50 \mathrm{mg} / \mathrm{kg} / \mathrm{day}$. Ovarian weight appeared to decrease with increasing dose levels of the compound, but only the $25 \mathrm{mg} / \mathrm{kg}$ dosage group showed statistically significant depression. The other organ weights did not show effects which could be attributed to the compound and PMHI also failed to influence oestrous cycles during the treatment period as judged by daily examination of vaginal smears. The data presented in Table 5 indicate that treatment of female rats with PMHI for 21 days at dosages up to $50 \mathrm{mg} / \mathrm{kg} /$ day did not interfere with normal fertility.

Table 5. Effects of PMHI on the fertility of the female rat

\begin{tabular}{c|c|c|c|c|c}
\hline $\begin{array}{c}\text { PMHI } \\
(\mathrm{mg} / \mathrm{kg} / \text { day })\end{array}$ & $\begin{array}{c}\text { No. of } \\
\text { rats }\end{array}$ & $\begin{array}{c}\text { No. } \\
\text { pregnant }\end{array}$ & $\begin{array}{c}\% \\
\text { Pregnant }\end{array}$ & $\begin{array}{c}\text { Mean no. } \\
\text { of young }\end{array}$ & $\begin{array}{c}\text { Mean weight }(\mathrm{g}) \\
\text { of young }\end{array}$ \\
\hline 0 & 6 & 5 & 83 & $12 \cdot 0$ & $14 \cdot 6$ \\
$6 \cdot 25$ & 6 & 6 & 100 & $11 \cdot 5$ & $14 \cdot 7$ \\
$12 \cdot 50$ & 6 & 6 & 100 & $12 \cdot 3$ & $15 \cdot 2$ \\
$25 \cdot 00$ & 6 & 6 & 100 & $12 \cdot 2$ & $13 \cdot 7$ \\
$50 \cdot 00$ & 4 & 4 & 100 & $12 \cdot 0$ & $14 \cdot 3$ \\
\hline
\end{tabular}

The PMHI was administered orally once daily for 21 consecutive days and the females were then kept with untreated males.

\section{DISCUSSION}

The data obtained in these experiments indicate that administration of PMHI causes sterility in male rats as a consequence of antispermatogenic activity. At low dosage levels $(3 \mathrm{mg} / \mathrm{kg}$ ), the action was reversible, but animals given $6.25 \mathrm{mg} / \mathrm{kg} /$ day or more remained sterile for 19 weeks following the treatment period. Since the testicular phase of spermatogenesis in the rat requires 48 days, and the epididymal phase has been estimated to require about 14 days (Jackson, 1966), PMHI-treated rats $(6 \cdot 25 \mathrm{mg} / \mathrm{kg} /$ day and above) were still 
sterile at least two full spermatogenic cycles after the treatment period. The testicular histology of these rats 19 weeks after the last administration of the compound was similar to that immediately after the treatment period and revealed no evidence of regeneration, so that the effect could be permanent.

It seems unlikely that the effects on the testes observed with PMHI are mediated by suppression of pituitary gonadotrophin production and/or secretion. Although depression of secondary sex organ weights in male rats occurred at some dosage levels of the compound suggestive of possible effects on Leydig cell function, this was not associated with notable depression of libido or mounting behaviour. It should also be noted that PMHI at an equal dose by weight caused a greater reduction in testis weight than either methallibure or diethylstilboestrol, two known antigonadotrophins, but was less effective than these in reducing seminal vesicle and ventral prostate weights. Both diethylstilboestrol and methallibure produced greater reductions in secondary sex organ weights than in gonadal weight, while the opposite was true for PMHI.

The destruction of the spermatogenic epithelium observed after high dosage of PMHI argues against a mechanism involving pituitary suppression, since comparable changes are not seen in hypophysectomized male rats or as a result of treatment with compounds suppressing pituitary gonadotrophin secretion. A long-acting antigonadotrophic agent could cause prolonged antifertility effects, but is an unlikely explanation in view of the preceding comment.

The absence of effect by PMHI on the oestrous cycle and fertility in the female rat provides further evidence against pituitary gonadotrophin suppression as a proposed mechanism of action, since antigonadotrophins specific to either sex have not been reported. Sex-dependent differences in the metabolism of PMHI as an explanation is unlikely, since there is no evidence to suggest that such metabolic differences exist.

The antispermatogenic effect of PMHI appears to differ from that of WIN 18446, nitrofurazone and other spermatogenesis inhibitors (Gomes, 1970) in regard to its reversibility, cell types affected and effects upon secondary sex organs. Additional studies will be required to delineate these apparent differences.

The most obvious explanation for the effects of PMHI would be that the compound has a direct effect on the testes, primarily on the cellular components of the spermatogenic tubules with a lesser effect on the Leydig cells.

\section{ACKNOWLEDGMENTS}

We are grateful to Dr S. Sadek for taking the photomicrographs, and for his comments concerning the testicular histology. We would like to thank Dr B. Heath-Brown, Research Department, Roche Products Limited, Welwyn Garden City, Herts, England, who was responsible for the synthesis of PMHI and supplied us with generous quantities of the preparation. We also acknowledge with gratitude Winthrop Laboratories, New York, N.Y., Eaton Laboratories, Norwich, N.Y., and Ayerst Laboratories, New York, N.Y., for samples of WIN 18446, nitrofurazone, and methallibure, respectively. 


\section{REFERENCES}

Beyler, A. L., Potts, G. O., Coulston, F. \& Surrey, A. R. (1961) The selective testicular effects of certain bis(dichloroacetyl) diamines. Endocrinology, 69, 819.

Gomes, W. R. (1970) Chemical agents affecting testicular function and male fertility. In The Testis, Vol. 3, p. 483. Eds. A. D. Johnson, W. R. Gomes and N. L. VanDemark. Academic Press, New York.

Jackson, H. (1966) Antifertility Compounds in the Male and Female. Charles C. Thomas, Springfield. JAckson, H. (1970) Antispermatogenic agents. Br. med. Bull. 26, 79.

Jackson, H. (1973) Chemical methods of male contraception. Am. Scient. 61, 188.

Nelson, W. O. \& Steinberger, E. (1953) Effects of nitrofuran compounds on the testes of the rat. Fedn Proc. Fedn Am. Socs exp. Biol. 12, 103.

Walpole, A. L. (1965) Non-steroidal agents inhibiting pituitary gonadotrophic function. In Agents Affecting Fertility, p. 159. Eds. C. R. Austin and J. S. Perry. Little, Brown \& Co., Boston. 